Bartın University Journal of Faculty of Education, 8(1), 161-178

Bartın Üniversitesi Eğitim Fakültesi Dergisi, 8(1), 161-178

buefad.bartin.edu.tr

\title{
Perfectionism, Irrational Beliefs, Need for Social Approval and Gender as Predictors of Parent Exam Anxiety
}

\author{
Kemal BAYTEMIR*a
}

\begin{tabular}{l} 
Article Info \\
\hline DOI: $10.14686 /$ buefad.417814 \\
\hline Article History: \\
Received $\quad 22.04 .2018$ \\
Accepted $\quad 22.12 .2018$ \\
Published $\quad 01.02 .2019$ \\
\hline Keywords: \\
Parent exam anxiety \\
Perfectionism \\
Irrational beliefs \\
Need for social approval \\
\hline Article Type: \\
Research article
\end{tabular}

\begin{abstract}
The purpose of the current study was to examine the role of perfectionism, irrational beliefs, need for social approval and gender as predictors of parent exam anxiety. The participants of the study were 178 parents $(113(63.48 \%)$ female and 65 $(36.52 \%)$ male) living in a province in the Central Black Sea Region in Turkey. The mean age of the participants was 42.28, $\mathrm{Sd}=5.90$. Personal Information Form, Need for Social Approval Scale, Irrational Beliefs Scale, Exam Anxiety Scale for Parents and APS Perfectionism Scale were employed as the data collection tools in the study. Pearson Correlation Coefficient for the correlation of variables and Multiple Regression Analysis for the predictive power of independent variables were utilized in analyzing the data. According to the results of the research, positive perfectionism and social approval were significantly related to the parent exam anxiety, but the contributions in the regression model were found non-significant. It was also found that negative perfectionism, irrational beliefs and gender predicted $26 \%$ of parent exam anxiety. Negative perfectionism, gender and irrational beliefs contributed to the model most, respectively. Findings obtained from the research were discussed and interpreted in the direction of the literature and further suggestions were made for researchers and practitioners studying in the field of psychological counseling and guidance.
\end{abstract}

\section{Ebeveyn Sınav Kaygısının Yordayıcıları Olarak Mükemmelliyetçilik, Akılcı Olmayan İnançlar, Sosyal Onay İhtiyacı ve Cinsiyet}

\begin{tabular}{|c|c|}
\hline \multicolumn{2}{|c|}{ Makale Bilgisi } \\
\hline \multicolumn{2}{|c|}{ DOI: 10.14686/buefad.417814 } \\
\hline \multicolumn{2}{|c|}{ Makale Geçmişi: } \\
\hline Geliş & 22.04 .2018 \\
\hline Kabul & 22.12 .2018 \\
\hline Yayın & 01.02 .2019 \\
\hline \multicolumn{2}{|c|}{$\begin{array}{l}\text { Anahtar Kelimeler: } \\
\text { Ebeveyn s1nav kaygıs1, } \\
\text { Mükemmelliyetçilik, } \\
\text { Akılc1 olmayan inançlar, } \\
\text { Sosyal onay ihtiyac1, }\end{array}$} \\
\hline \multicolumn{2}{|c|}{$\begin{array}{l}\text { Makale Türü: } \\
\text { Araştırma makalesi }\end{array}$} \\
\hline
\end{tabular}

$\ddot{O} \mathbf{z}$

Bu çalışmanın amacı ebeveyn sınav kaygısının yordayıcıları olarak sosyal onay ihtiyacı, akılcı olmayan inançlar, mükemmeliyetçilik ve cinsiyetin rolünü incelemektir. Araştırmanın çalışma grubunu Orta Karadeniz'de yer alan bir il merkezindeki $113(\% 63.48)$ kadın ve 65 (\%36.52) erkek olmak üzere toplam 178 ögrenci velisi oluşturmaktadır. Araştırmaya katılanların yaş ortalaması 42.28, Ss= 5.90'dür. Araştırmada veri toplama araçları olarak, Kişisel Bilgi Formu, Sosyal Onay İhtiyacı Ölçeği, Akılcı Olmayan İnançlar Ölçeği, Ebeveyn Sınav Kaygısı Ölçeği ve APS Mükemmeliyetçilik Ölçeği kullanılmıştır. Verilerin analizinde değişkenler arasındaki ilişkilerin incelenmesi için için Pearson Momentler Çarpımı Korelasyon Katsayısı ve bağımsız değişkenlerin bağımlı değişkenleri yordama gücünü belirlemek için Çoklu Regresyon Analizi kullanılmıştır. Araştırma sonucunda olumlu mükemmeliyetçilik ve sosyal onay ebeveyn sınav kaygısı ile anlamlı olarak ilişkili olsa da regresyon modelindeki katkıları anlamlı bulunmamıştır. Olumsuz mükemmeliyetçilik, cinsiyet ve akılcı olmayan inançların hep birlikte ebeveyn sınav kaygısının yüzde 26'sını açıladığı bulunmuştur. Modele sirasıyla, mükemmeliyetçiliğin daha sonra cinsiyetin ve son olarak akılcı olmayan inançların katkı sağladığ

\footnotetext{
*Corresponding Author: kemalbaytemir@mail.com

${ }^{a}$ Asst. Prof. Dr., Amasya University/Turkey, https://orcid.org/0000-0002-7865-4325
} 


\section{Introduction}

Every year, millions of students are subjected to various exams to measure academic achievement at various levels of education in Turkey (Baytemir and İlhan, 2018). Beginning from exam preparation to the time of doing exams, not only students but also parents become an important part of this process. Exam, which is one of the most important predictors of measuring achievement in education, causes negative feelings like anxiety not only in students but also in parents (Harpell and Andrews, 2012). This feeling, called exam anxiety, may lead to negative physiological, psychological and behavioral consequences on the individual when not wellmanaged (Chin, Williams, Taylor and Harvey, 2017; Yıldırım, 2007).

Exam anxiety, defined as a multidimensional structure including cognitive, social, behavioral, and emotional reactions (Hong, 1998), is one of the obstacles to students' academic achievement. Many studies have concluded that exam anxiety have a negative impact on academic performance (McDonald, 2001; Morris and Liebert, 1970, Trifoni and Shahini, 2011). Literature review showed there are many factors affecting students' exam anxiety including perfectionism (Soysa and Weiss, 2014; Eum and Rice, 2011; Hanımoğlu and İnanç, 2011), irrational beliefs (Güler and Çakır, 2013; Wong, 2008), gender (Chapell et al, 2015; Güler and Çakır, 2013; Trifoni and Shahini, 2011) and parental factors (parents' high expectations for achievement, extreme interventionist attitudes, anxious approach etc. (Besharat, 2003; Milgram and Toubiana, 1999; Shadach and Ganor-Miller, 2013; Woodruff-Borden, Morrow, Bourland and Cambron, 2002). Parents' expectations and attitudes towards exam along with the feeling of anxiety towards their children's doing exams constitute an important aspect of exam period. According to Baytemir and İlhan (2018) parents are anxious about exams. In other words, the parents feel in the same way as the children prepare for exams in exam period. Baytemir and İlhan (2018) stated it as parent exam anxiety. In their studies, parent exam anxiety was also considered as a multi-dimensional structure such as students' exam anxiety and was expressed as a structure containing the dimension of worry and physiological. A recent study (Baytemir, 2018) showed that parent exam anxiety was significantly related to students' exam anxiety.

Similar to exam anxiety, a number of studies have examined how parents' and children's anxiety are correlated as a personality trait. The mentioned studies (Alisinanoglu and Ulutas, 2003; Burstein and Ginsburg, 2010) showed that children's feeling of anxiety was significantly related to parent anxiety. Woodruff-Borden et al. (2002) found anxious parents were not successful in teaching their children how to effectively cope with stressful life events. In another experimental study (Burstein and Ginsburg, 2010), children were exposed to two different experimental conditions based on vocabulary testing. In the first stage, parents were asked to talk to their children in an anxious way, and in the other stage they were asked to talk to them safely and act comfortably. Findings showed children were more anxious in the first experimental setting than they were in the latter and were more averse to testing. As can be seen, parent anxiety levels have a significant impact on children's anxiety.

Research in the literature reveals that similar intra- and interpersonal factors are influential not only on children but also on adults. For instance, individuals who expect extra approval from others (Soygüt, Karaosmanoğlu and Çakir, 2009; Tanaka-Matsumi and Kameoka, 1986; Karaşar and Öğülmüss, 2016), who have a perfectionist attitude (Chang, 2000; Mor, Day, Flett and Hewitt, 1995), and who reflect more irrational beliefs towards various life circumstances (Bridges and Harnish, 2010) are more anxious. Upon analyzing the relationship between exam anxiety and performance, this fact seems to be attributed mostly to the dimension of anxiety which encompass individuals' cognition (Cassady, 2002). According to the Cognitive Behavioral Approach (Beck, 1993; Beck and Clark, 1997) the main reasons for anxiety are not the events but the meanings attributed by the individuals to the situations/events. Automatic thought, intermediate beliefs and core beliefs, also called cognitive triad, are cognitive structures that direct emotional reactions of individuals. Similarly, Ellis (2010) emphasizes that irrational beliefs about situations lead to negative feelings. These irrational beliefs may be sharply expressed by absolutely musts, illogical overgeneralization or awfulizing. According to this approach, parents' irrational beliefs such as "my child must get a good grade", "it is too bad if they get a negative result" or "it is horrible if they cannot reach the desired result" cause anxiety. Like those who have non-functional thoughts or irrational beliefs, parents with perfectionist attitudes about their children are also anxious about not getting the desired results. Higher standards are often emphasized in the literature as one of the characteristics of perfectionism (Castro and Rice, 2003). Perfectionists suffer, feel guilt and shame when these high standards cannot be reached, and criticize themselves in a painful way (Silverman, 2007). Perfectionism, mostly regarded as being flawless, is widely accepted as negative trait (Blatt, 1995; Pacht, 
1984). Later on, the positive aspects were also emphasized besides the negativity of perfectionism (Ashby and Rice, 2002; Hamachek, 1978; Silverman, 2007). Accordingly, negative perfectionists never get satisfied with their endeavors and always have the feeling that they should do better. In contrast, positive perfectionists have an intense desire to reach their goals and strive so that they have a sense of achievement and personal satisfaction (Ashby and Rice, 2002; Silverman, 2007). Parents who set high standards for their children, who have high expectations, and who do not find their children's efforts adequate can be worried about their children's reaching the specified goals.

In addition, parents can admire their children's achievement or be uncomfortable with their failures. This may be related to the personality traits of the parents, as well as the comments and thoughts by close others or relatives on children's success and failure. In other words, this may be about parents' need for social approval. Need for social approval appears when someone needs others' admiration (Fehr and Falk, 2001) which is resulted in anxiety fearing that close others will express their opinions about them (Karaşar, 2014). Considering the Turkish culture, it may be said to have a more relational self-construal. According to Kağıtçıbaşı (2010), what lies behind in the construal of relational self is being sensitive to others' opinions and fulfilling the expected duties and behaviors. Some of the individuals' selves contain others' selves. Self-construal affects how individuals perceive themselves, others and the world, their emotions, thoughts and behaviors. In this case, a parent may be vulnerable to failure if the child fails, or sensitive to evaluate others' children.

As has been stated so far, parent exam anxiety is significantly related to students' exam anxiety. Moreover, parent anxiety also seems related to perfectionism, irrational beliefs and the need for social approval. From this point of view, the purpose of the current study is to examine the effects of perfectionism, irrational beliefs, gender, and need for social approval on parent exam anxiety.

\section{Method}

\section{Research Design}

Correlational design was the design of the current study. According to Heppner, Wampold, and Kivlighan (2013), correlational designs are used in order to examine relationships between two or more variables. The predictive variables of the research were need for social approval, irrational beliefs, perfectionism and gender. The predicted variable was the parent exam anxiety.

\section{Study Group}

The participants of the study consisted of 178 parents, $113(63.48 \%)$ females and $65(36.52 \%)$ males living in a province in the Central Black Sea Region. The participants' mean age was 42.28, $\mathrm{Sd}=5.90$. The distribution of the children of the parents according to the classes is eighth grade, 77; ninth grade, 42; tenth grade, 19; eleven, 8; it is a total of 178.

\section{Data Collection Tools}

Personal Information Form, The Need for Social Approval Scale, The Irrational Beliefs Scale, The Exam Anxiety Scale for Parents and The APS Perfectionism Scale were employed as data collection tools. Below is the information about the attributes of measuring instruments.

The APS Perfectionism Scale. The first form of the original scale, developed by Slaney and Johnson (1992), was revised by Slaney et al. (Slaney and Ashby, 1996; Slaney et al., 2001). The revised final version of the scale consists of 23 items in three dimensions as "High Standards" (7 items), "Order" (4 items) and "Discrepancy" (12 items). Cronbach alpha values calculated for the reliability are .85 for High Standards, .82 for Order, 91 for Discrepancy, respectively. The Turkish adaptation was carried out by Sapmaz (2006). In the adaptation study, an exploratory factor analysis was conducted to determine the validity of the scale. As a result of the analysis, four factors were detected as differently from the original three ones. These dimensions are called high standards, order, dissatisfaction and discrepancy. These factors predict $50.22 \%$ of the total variance. Criterion validity was also analyzed. Accordingly, it was found that there was a correlation of .24 between multidimensional perfectionism scale and adaptive perfectionism, and a correlation of .51 with maladaptive perfectionism. In the reliability calculations, Cronbach Alpha values for each sub-dimension were determined as .72 for High Standard, .83 for Order, .81 for Dissatisfaction, and .72 for Discrepancy. Overall reliability coefficient for positive perfectionism (Consolidated subscales of Standard and Order) was found .79 for 
positive perfectionism; and .82 for negative perfectionism (combined subscales of Dissatisfaction and Discrepancy).

The Irrational Belief Scale (IBS-S). The IBS-S, developed by Türküm (2003) in order to measure undergraduates' irrational beliefs, consists of three sub-dimensions (need for approval, interpersonal relationships and self) and 15 items. It is a Likert-type scale as the lowest obtainable score is 15 and the highest is 75 . The higher the score is, the higher the level of irrational belief is. Structure and criterion validity were also examined. As a result of exploratory factor analysis (AFA), three factors were determined to predict the $42.9 \%$ of the total variance. Upon analyzing criterion validity, it was found to be significantly related to the Non-Functional Attitudes Scale (FOQ) in the positive direction. Nevertheless, there was no significant correlation between exam anxiety and Beck Depression Inventory. For reliability practices, the internal consistency coefficient was found .75 for all scales and the test-retest reliability coefficient was .81 .

The Need for Social Approval Scale. The scale, developed by Karaşar (2014) to measure the need for approval is a five-point Likert scale consisted of three sub-dimensions, namely sensitivity to others' judgments, positive impression and social withdrawal which are related to need for social approval. Higher scores on the Need for Social Approval Scale indicate that need for social approval is high, too. Confirmatory Factor Analysis (CFA) was performed for validity practices of the scale. Basing on the CFA results from the two samples, fit indices were found to be at proper levels. While the fit indices for the first group are; $\mathrm{x}^{2} / \mathrm{sd}=2.11$, $\mathrm{RMSEA}=.06, \mathrm{NNFI}=.94, \mathrm{CFI}=.95, \mathrm{RMR}=.06, \mathrm{NFI}=.90, \mathrm{IFI}=.95$, they are as follows for the second group; $\mathrm{x}^{2} / \mathrm{sd}=2.23, \mathrm{RMSEA}=.06, \mathrm{NNFI}=.95, \mathrm{CFI}=.96, \mathrm{RMR}=.06, \mathrm{NFI}=.92, \mathrm{IFI}=.96$. The internal consistency coefficients calculated for the reliability values of the sub-dimensions of the scale are as follows; .83 for sensitivity to others' judgments, .80 for social withdrawal and .80 for positive impression. The overall inner consistency scale, Cronbach alpha coefficient was found to be .90 . The pretest - post-test reliability of the scale was found to be .90 .

The Exam Anxiety Scale for Parents (EASP). EASP was developed by Baytemir and İlhan (2018) to measure parent exam anxiety. The validity and reliability practices of the scale were performed on two different samples. Explanatory and confirmatory factor analyses (CFA) were performed on the data obtained from the first sample. According to the results of the exploratory factor analysis (AFA), it was found that the scale was composed of two dimensions and 18 items. These two factors were named as worry and physiologic basing on the literature review. The total variance predicted for the two dimensions was $55.44 \%$. The DFA was performed to verify the result obtained from the AFA. The DFA results showed that the model produced adequate fit index $\left(\chi^{2} / \mathrm{df}=2.2, \mathrm{RMSEA}=.058, \mathrm{CFI}=.98, \mathrm{NFI}=.97, \mathrm{TLI}=.98\right)$. Criterion validity practice was performed on the data obtained from the second sample. Accordingly, there was a moderate significant relationship between parent exam anxiety and trait anxiety as .51 , and as .39 between exam anxiety and state anxiety. For reliability of the scale, Cronbach's Alpha values were examined in the two samples and found .91;.93 for the whole of the scale, $.88 ; .88$ for the anxiety sub-dimension and $.91 ; .91$ for the physiological sub-dimension.

\section{Data Collection}

The data collection tools and the personal information form were administered face to face and mailed to those who voluntarily participated in the research. Participants responded scale items approximately in 30-35 minutes

\section{Data Analysis}

Descriptive statistics, Pearson correlation coefficient and backward method of multiple regression analysis methods were used in analyzing the data. Mahalanobis distance values were calculated to determine whether the data had extreme values that would damage the assumptions of "linearity" and "normality". Mahalanobis distance values were calculated. Two observations (multivariate outliers) with Mahalanobis value larger than $\chi^{2}(6 ; 01)=16.81$ were excluded. Values of kurtosis and skewness were examined to determine the distribution of normality. Values of kurtosis and skewness displayed that the data had a normal distribution (need for social approval: skewness, .03 and kurtosis .38; irrational beliefs: skewness, -42 and skewness .20; parent exam anxiety: skewness, .42 and kurtosis -.69, positive perfectionism: skewness, -67 and kurtosis .70; negative perfectionism; skewness, .21 and kurtosis, -.26). The correlations between variables showed that the correlation values varied between .20 and .51 , and that there was no problem in multicollinearity. 


\section{Findings}

This section includes descriptive statistics and correlations among the variables (Table. 1). The findings of the multiple regression analysis are listed below. Table 1 displays the descriptive statistics and correlation values for the variables analyzed in the research.

Table 1. Pearson Correlation Coefficients and Descriptive Statistics

\begin{tabular}{|c|c|c|c|c|c|c|c|c|c|}
\hline Variables & 1 & 2 & 3 & 4 & 5 & 6 & $\overline{\bar{X}}$ & $\overline{\text { Ss }}$ & $\bar{\alpha}$ \\
\hline \multicolumn{10}{|l|}{ Gender } \\
\hline Need for social approval & -.11 & & & & & & 72.01 & 16.45 & .90 \\
\hline Irrational beliefs & -.01 & $.51 * *$ & & & & & 58.17 & 7.02 & .69 \\
\hline Positive perfectionism & .10 & $.20 * *$ & $.38 * *$ & & & & 59.75 & 9.77 & .82 \\
\hline Negative perfectionism & -.12 & $.39 * *$ & $.39 * *$ & $.44 * *$ & & & 43.30 & 13.69 & .85 \\
\hline Parent Exam Anxiety & $-.28 * *$ & $.31 * *$ & $.29 * *$ & $.29 * *$ & $.45^{* *}$ & & 45.16 & 15.90 & .93 \\
\hline
\end{tabular}

As seen in Table 1, gender was found to be significantly related only to parent exam anxiety (-.28, $p$ $<.01)$, but not to other variables. The need for social approval showed the highest significant relationship with irrational beliefs $(\mathrm{r}=.51, p<.01)$. Then, it was found to be positively significantly related to negative perfectionism, parent exam anxiety and positive perfectionism, respectively. Irrational beliefs were observed to be positively related to positive and negative perfectionism and parent exam anxiety. Both positive and negative perfectionism were significantly related to each other and to parent anxiety. A multiple regression analysis was conducted to determine what degree the independent variables, namely gender, need for social approval, irrational beliefs, and positive and negative perfectionism predicted parent exam anxiety; the results are presented in Table 2.

Table 2. Multiple Regression Analysis of The Effect Gender, Irrational Beliefs, Negative Perfectionism on Parent Exam Anxiety

\begin{tabular}{lllllll}
\hline Model & Predictive Variables & B & $\begin{array}{l}\text { Standard } \\
\text { Error }\end{array}$ & $\boldsymbol{\beta}$ & $\boldsymbol{t}$ & $\boldsymbol{p}$ \\
\hline Model 1 & Constant & 16.42 & 9.65 & & 1.701 & .09 \\
& Gender & -7.69 & 2.19 & -.23 & -3.52 & .01 \\
& Irrational beliefs & .19 & .18 & .08 & 1.04 & .30 \\
& Need for social approval & .10 & .08 & .10 & 1.29 & .20 \\
& Positive perfectionism & .10 & .12 & .06 & .83 & .40 \\
& Negative perfectionism & .37 & .09 & .32 & 4.09 & .00 \\
\hline Model 2 & Constant & 19.05 & 9.11 & & 2.09 & .04 \\
& Gender & -7.41 & 2.16 & -.23 & -3.43 & .01 \\
& Irrational beliefs & .23 & .18 & .10 & 1.29 & .20 \\
& Need for social approval & .09 & .08 & .10 & 1.24 & .22 \\
& Negative perfectionism & .40 & .08 & .34 & 4.74 & .00 \\
\hline Model 3 & Constant & 19.646 & 9.112 & & 2.156 & .03 \\
& Gender & -7.67 & 2.15 & -.23 & -3.57 & .01 \\
& Irrational beliefs & .32 & .16 & .14 & 2.01 & .04 \\
& Negative perfectionism & .42 & .08 & .36 & 5.13 & .00 \\
\hline
\end{tabular}


In the first step of the analysis (Model 1), positive perfectionism, which had the weakest relationship ( $\beta=$ $.06, p>.05)$ with the dependent variable, was removed from the model since its contribution to the model was little. In the second step of the analysis (Model 2), need for social approval, which had the weakest relationship $(\beta=.09, p>.05)$ with the dependent variable, was also removed from the model. Thus, with the backward method, the variables contributing the least to the model among the independent variables were detected and excluded. Hence, in the final model (Model 3), only gender, irrational beliefs, and negative perfectionism were found to contribute significantly to the model. The model was consequently found significant as a whole $(\mathrm{R}=$ $\left..52, \mathrm{R}^{2}=.26, \mathrm{~F}=21,23, p<.01\right)$. Negative perfectionism, gender, and irrational beliefs predicted $26 \%$ of the total variance of parent exam anxiety.

According to the standardized regression coefficient $(\beta)$, negative perfectionism $(\beta=.36, p<.01$, gender $(\beta=$ $-.23, p<.01)$, and irrational beliefs $(\beta=.14, p<.05)$ were observed to provide the most contribution. Basing on that result, the most powerful variable in predicting parent exam anxiety was negative perfectionism; gender was the second most powerful predictor. Irrational beliefs were found to be less powerful predictors of parent exam anxiety compared to the first two variables.

\section{Discussion and Conclusion}

Negative perfectionism, gender, and irrational beliefs predicted $26 \%$ of the total variance of parent exam anxiety. Although positive perfectionism and need for social approval were significantly related to the parent exam anxiety, their contributions in the regression model were found non-significant. According to the standardized regression coefficient $(\beta)$ the biggest contribution to the model is made by negative perfectionism and, it is followed by gender and irrational beliefs provided. Although need for social approval and positive perfectionism were significantly related to parent exam anxiety, they did not make a meaningful contribution to the model. These findings are consistent with the findings in the literature. In many studies, negative perfectionism is seen a better predictor of exam anxiety (Hanımoğlu and İnanç, 2011; Eum and Rice, 2011). Perfectionism is often considered in a negative way. In negative perfectionism, individuals are never satisfied with their endeavors, but the positive perfectionists intensely strive to achieve their goals and as a result they enjoy satisfaction (Hamachek, 1978; Ashby and Rice, 2002; Silverman, 2007). Thus, parents having negative perfectionism may experience higher levels of an anxiety on the exam performance of their children. Parents having positive perfectionism focus on their children's endeavors and achievements and thus feel less anxious about their exams. For instance; when a child gets 90 out of 100, a parent with negative perfectionism asks the reasons why his/her child has not got 100, but a positive perfectionist parents may think that the score 90 is satisfying.

According to another finding from the study, not only parents with negative perfectionism but also parents with irrational beliefs are pessimistic and worried about their children's performance. These findings are consistent with the findings in the literature exam anxiety is associated with irrational beliefs. (Güler and Çakır, 2013; Wong, 2008). Having successful results on exams are thought to be an essential condition in order to be able to get a satisfying job in the future. Many people would appreciate good results that children get from exams, and achievement in exams may be seen as an important indication of academic success. Therefore, both child and parents may start thinking that the exam results must be very good. As a result, exams become one of the very important matters for both children and parents. Just as children have irrational beliefs (Güler ve Çakır, 2013; Wong, 2008) parents may also have irrational beliefs about exams. As Ellis (2010) points out, irrational beliefs determine feelings that people will experience. Irrational beliefs lead to improper results; facts are often exaggerated and overgeneralised (Elçin Boyacıoğlu and Küçük, 2011). Parents having "must" irrational beliefs may feel anxious. Apart from believing this way, parents may also have overgeneralizing and awfulizing irrational beliefs. In this case, parents' worst scenario attitude such as "what if my child cannot get a good grade" worsens the situation and it might also lead parents to decision making on their children's failure or judge them when they keep this attitude overstated. Therefore, this irrational belief structure causes anxiety.

Gender seems to be a significant predictor of exam anxiety, similar to the results of the current study (Trifoni and Shahini, 2011; Chapell et al., 2015). In other words, girls have more exam anxiety than boys.It was also found that female parents were more worried about their children's having a exam than male parents. There may be many reasons behind this. First of all, anxiety disorder is more prevalent among women than it is among men (Feingold; 1994; McLean Asnaani, Litz and Hofmann, 2011). In addition, it was seen that the neurotoxicity levels of girls is higher than that of boys in personality studies (Chapman, Duberstein, Sörensen 
and Lyness, 2007;Tatlılığlu, 2014). Therefore, women may be more worried than men in the case of a more specific anxiety such as exam anxiety. Another reason for gender differences can be interpreted by sociopsychological processes. Accordingly, the cause of this differentiation may be related to the gender roles imposed on women and men. Social gender roles are the internalization of expectations related to both men's and women's personality traits and social behavior types (Costa, Terracciano and McCrae, 2001). Learning about gender roles is achieved through the internalization of the characteristics and behaviors of the individual in the process of socialization. The role of femininity is more associated with docility, understanding, courtesy, being more aware of the emotions of others, while masculinity is more associated with aggression, hiding emotions, competitiveness (Ersöz, 2010). Hence, the fact that a woman growing up in Turkish society is more compassionate may be attributed to the fact that they are more worried than men, and that more intense emotional life of them is more acceptable. At the same time, the perception that a Turkish woman is more responsible for raising children (Özensel, 2004) may cause mothers to feel to take on extra responsibility for their children's exams. Thus, the mother may be more worried that the child will get a lower score on the exam or not be able to get adequate achievement.

Based on the findings of this study, the experts in the field of psychological counseling can conduct individual and in particular group psychological counseling to reduce negative perfectionism and irrational beliefs of parents on exam anxiety. Other personality traits (focus of control, self-esteem, Need for success, self-acceptance etc.) that may affect parent exam anxiety may be examined on future parental exam anxiety studies. Parental exam anxiety can be investigated according to gender, achievement, and the number of children, regarding children's educational levels. As women were found to be more worried about their children's exams, the socio-psychological bases of this fact may be examined.. For example, in addition to personality traits, the expectations of the society from the woman, the roles of the woman at the home, child care, and parents' school-related tasks can be considered in this context. In different cultures, this and similar models may be tested if parents' anxiety levels about their children's doing exams are determined.

Finally, the current study has some limitations. Data were collected from parents living in a province in northern part of Turkey. For this reason, this reality should be taken into account when making generalizations. Considering the proportion of the participants, female participants outnumbered men. This fact can be considered as another limitation. Future studies may consider larger sampels sizes for generalizability purposes for representing Turkish population. 


\section{Ebeveyn Sınav Kaygısının Yordayıcıları Olarak Mükemmelliyetçilik, Akılcı Olmayan İnançlar, Sosyal Onay İhtiyacı ve Cinsiyet}

\section{Giriş}

Her yıl Türkiye'de milyonlarca öğrenci eğitimin farklı kademelerinde başarılarının ölçülmesi amacıyla çeşitli sınavlara tabi tutulmaktadır (Baytemir ve İlhan, 2018). Sınavlara hazırlanma sürecinden sınav anına kadar en başta öğrencinin kendisi olmak üzere öğrencinin ailesi de bu sürecin önemli bir parçası haline gelmektedir. Eğitimde başarıyı ölçmenin en önemli yordayıcılarından biri olan sınav, sadece öğrencilerde değil, aynı zamanda onların anne babalarında da kaygı gibi (Harpell ve Andrews, 2012) bir takım olumsuz duygulara yol açmaktadır. Sınav kaygısı olarak adlandırılan bu duygu, iyi yönetilemediğinde bireyler üzerinde fizyolojik, psikolojik ve davranışsal bir takım olumsuz sonuçlara neden olabilmektedir (Chin, Williams, Taylor ve Harvey, 2017; Yıldırım, 2007).

Bilişsel, sosyal, davranışsal, duyuşsal tepkileri içeren çok boyutlu bir yapı olarak tanımlanan sınav kaygısı (Hong, 1998) öğrencilerin akademik başarılarının önündeki engellerden bir tanesidir. Pek çok çalışmada sınav kaygısının akademik performansı olumsuz yönde etkilediği (McDonald, 2001; Morris ve Liebert, 1970; Trifoni ve Shahini, 2011) sonucuna varılmıştır. Öğrencilerde sınav kaygısının ortaya çıkmasında kişisel ve sosyal faktörler etkili olmaktadır. Alanyazında öğrencilerin sınav kaygılarını bir çok etmenin yanı sıra mükemmeliyetçilik (Soysa ve Weiss, 2014; Eum ve Rice, 2011; Hanımoğlu ve İnanç, 2011), akılcı olmayan inançlar (Güler ve Çakır, 2013; Wong, 2008) cinsiyet (Chapell vd, 2015; Güler ve Çakır, 2013; Trifoni ve Shahini, 2011) ve aile faktörünün (ebeveynlerin yüksek başarı beklentileri, aşırı müdahaleci tutumları, kaygılı yaklaşım vb.) etkili olduğu bilinmektedir (Besharat, 2003; Milgram ve Toubiana, 1999; Shadach ve Ganor-Miller, 2013; Woodruff-Borden, Morrow, Bourland ve Cambron, 2002).

Ebeveynlerin çocuklarının sınavlarına ilişkin beklenti ve tutumları gibi çocuğunun sınavına ilişkin sınav kaygısı yaşaması da sınav sürecinin önemli bir yönünü oluşturmaktadır. Baytemir ve İlhan'a (2018) göre ebeveynler, çocuklarının sınavları için kaygılanmaktadır. Başka bir ifade ile çocuklar sınavlara hazırlanırken ve sınav süresince yaşadıkları kaygıların benzerini ebeveynler de yaşamaktadır. Baytemir ve İlhan (2018) bu durumu ebeveyn sınav kaygısı olarak ifade etmişlerdir. Onların çalışmalarında ebeveyn sınav kaygısı da öğrencilerin sınav kaygıları gibi çok boyutlu bir yapı olarak düşünülmüş ve kuruntu ve duyuşsallık boyutlarını içeren bir yapı olarak ifade edilmiştir. Son zamanlarda yapılan bir çalışmada (Baytemir, 2018) ebeveyn sınav kaygısı ile öğrencinin sınav kaygısının anlamlı olarak ilişkili olduğu görülmüştür.

Sınav kaygısına benzer şekilde bir kişilik özelliği olarak ebeveynin ve çocuğun kaygılarının nasıl ilişkili olduğunu inceleyen bir çok çalışma gerçekleştirilmiştir. Bu çalışmalar (Alisinanoğlu ve Ulutaş, 2003; Burstein ve Ginsburg, 2010) çocuklarda görülen kaygının ebeveynlerin kaygılarıyla ilişkili olduğunu ortaya koymaktadır. Woodruff-Borden vd., (2002) yapmış oldukları bir çalışmada kaygılı ebeveynlerin çocuklarına stresli olaylarla etkili bir şekilde nasıl başa çıkmaları gerektiğini öğretmekte başarılı olamadıklarını bulmuşlardır. Deneysel olarak yapılan başka bir çalışmada (Burstein ve Ginsburg, 2010) çocuklar kelime testiyle ilgili iki farklı deneysel ortama maruz bırakılmıştır. Birinci aşamada ebeveynlerden çocuklarına kaygılı konuşmalar yapmalarını, diğer aşamada ise güvenli ve rahatlatıcı konuşmalar yapmaları ve davranmalarını istemişılerdir. Bulgular, çocukların ilk deney ortamında diğerine göre daha fazla kaygılandıklarını ve testi yapma konusunda daha kaçınmacı davrandıklarını ortaya koymuştur. Görüldüğü üzere çocukların kaygılarında ebeveynlerin kaygı düzeylerinin anlamlı bir etkiye sahip olduğu anlaşılmaktadır.

Alanyazındaki araştırmalar sadece çocukların değil, yetişkinlerin de kaygılarında benzer kişi içi ve kişilerarası faktörlerin etkili olduğunu ortaya koymaktadır. Örneğin, başkalarından daha fazla onay bekleyen/sosyal beğenirliği yüksek (Soygüt, Karaosmanoğlu ve Çakir, 2009; Tanaka-Matsumi ve Kameoka,1986; Karaşar ve Ögülmüş, 2016), mükemmeliyetçi tutuma sahip (Chang, 2000; Mor, Day, Flett ve Hewitt, 1995) ve durumlar karşısında daha fazla akılcı olmayan inançlar sergileyen bireyler (Bridges ve Harnish, 2010) daha fazla kaygı yaşamaktadırlar. Sınav kaygısı performans ilişkisi incelendiğinde bunun daha çok bireyin bilişlerini içeren kuruntu boyutuyla ilişkili olduğu görülmektedir (Cassady, 2002). Bilişsel davranış̧̧ı yaklaşıma (Beck, 1993; Beck ve Clark, 1997) göre kaygıların asıl nedeni olaylar değil, bireylerin zihinlerinde olaylara/durumlara ilişkin yükledikleri anlamlardır. Bilişsel üçlü olarak da adlandırılan otomatik düşünceler, ara inançlar ve temel inançlar, bireylerin duygusal tepkilerini yöneten bilişsel yapılarıdır. Benzer şekilde Ellis (2010) durumdan ziyade duruma ilişkin akılcı olmayan inançların olumsuz duygulara neden olduğunu vurgulamaktadır. Bu akılcı olmayan inançlar 
keskin bir şekilde meli-malı gibi zorunluluk ifadeleri, aşırı genelleştirme ya da felaketleştirme olabilir. Bu yaklaşıma göre bir ebeveynin, "çocuğum mutlaka iyi bir yer kazanmalı", "olumsuz bir sonuç alırsa bu çok kötüdür", sınavlardan istediği sonuca ulaşamaz ise bu korkunçtur" tarzında akılcı olmayan düşünceleri beraberinde kaygıyı da getirmektedir.

İşlevsel olmayan düşünceler ya da akılcı olmayan inançlar gibi çocuğu hakkında mükemmeliyetçi tutuma sahip ebeveyn de beklentilerinin gerçekleşmeyeceği endişesi yaşamaktadır. Yüksek standartlar belirleme mükemmeliyetçiliğin karakteristik özelliklerinden biri olarak alanyazında sıklıkla vurgulanmaktadır (Castro ve Rice, 2003) Mükemmeliyetçiler, bu yüksek standartlara ulaşılamadığında acı çekmekte, suçluluk ve utanç duyguları yaşamakta ve kendilerini acımazsızca eleştirmektedirler (Silverman, 2007). İlk başlarda kusursuz olmaya yönelik olarak düşünülen mükemmeliyetçilik yaygın olarak olumsuz değerlendirilirken (Blatt, 1995; Pacht, 1984). sonraları mükemmeliyetçiliğin olumsuzluklarının yanında olumlu yönlerinin olduğu üzerinde durulmuştur (Ashby ve Rice, 2002; Hamachek, 1978; Silverman, 2007) Buna göre olumsuz mükemmeliyetçiler çabalarını asla yeterli bulmamakta ve her zaman daha iyisini yapmalıyım hissine sahip olmaktadırlar. Olumlu mükemmeliyetçiler ise amaçlarına ulaşmak için yoğun bir arzu duymakta ve çabalamakta böylece başarma ve hoşnutluk hissi ve kişisel doyum yaşamaktadırlar (Ashby ve Rice, 2002; Silverman, 2007). Çocukları için yüksek standartlar belirleyen, beklentileri yüksek olan ve çocuklarının çabalarını yeterli bulmayan ebeveynler belirlenen amaçlara ulaşma konusunda kaygı yaşayabilmektedir.

Aynı zamanda ebeveynler çocuklarının başarılarıyla övünebilir ya da başarısılıklarından rahatsızlık duyabilir. Bu durum anne-babanın kişisel özellikleri ile ilgili olabileceği gibi yakın çevresindeki eş ve dostlarının çocuğun başarı ve başarısızlığına ilişkin yorum ve düşünceleri ile ilgili olabilir. Başka bir ifade ile bu durum ebeveynin sosyal onay ihtiyacıyla ilişkili olabilir. Sosyal onay ihtiyacı, başkalarının hayranlığını kazanmayla (Fehr ve Falk, 2001) ve çevremdeki insanlar benim hakkımda ne söyler ne düşünür korkusuyla (Karaşar, 2014) ilgilidir. Türk toplumunun kültürü göz önüne alındığında daha çok ilişkisel benlik yapısına sahip olduğu düşünülebilir. Kağıtçıbaşına göre (2010) ilişkisel benlik yapısında başkalarının görüşlerine duyarlı olma, kendinden beklenen görev ve davranışları yerine getirme söz konusudur. Bireyin benliğinin bir kısmını başkalarının benliği oluşturur. Benliğin yapısı bireyin kendisini, başkalarını ve dünyayı nasıl algılayacağını, duygu, düşünce ve davranışlarını etkiler. Bu durumda bir anne baba çocuğunun başarısız olması durumunda kendini de başarısız olarak görebilir ya da başkalarının çocuğu hakkında değerlendirmelerine karşı hassas olabilir.

Buraya kadar ifade edildiği üzere öğrencinin sınav kaygısı ile ebeveyn sınav kaygısı anlamlı olarak ilişkilidir. Bunun yanında yetişkinlerin kaygılarının mükemmeliyetçilik, akılcı olmayan inançlar ve sosyal onay ihtiyacı ile ilişkili olduğu görülmektedir. Buradan hareketle bu araştırmanın amacı, ebeveyn sınav kaygısını etkileyebileceği düşünülen mükemmeliyetçilik, akılcı olmayan inançlar ve sosyal onay ihtiyacının yordayıcı rolünün incelenmesidir.

\section{Yöntem}

\section{Araştırma Modeli}

Bu çalışmada ilişkisel desen kullanılmıştır. Heppner, Wampold ve Kivlighan'a (2013) göre ilişkisel desenler iki ya da daha fazla değişken arasındaki ilişkileri araştırmak için kullanılırlar. Araştırmanın yordayıcı değişkenleri; sosyal onay ihtiyacı, akılcı olmayan inançlar, mükemmeliyetçilik ve cinsiyettir. Yordanan değişken ise ebeveyn sinav kaygisidir.

\section{Araştırma Grubu}

$\mathrm{Bu}$ araştırmanın katılımcıları Orta Karadeniz'de yer alan bir il merkezindeki 113 (\%63.48) kadın ve 65 (\%36.52) erkek olmak üzere toplam 178 öğrenci velisi oluşturmaktadır. Araştırmaya katılanların yaş ortalaması 42.28, Ss= 5.90'dür. Ebeveynlerin çocuklarının sınıflara göre dağılımına bakıldığında sekizinci sınıf, 77; dokuzuncu sınıf, 42; onuncu sınıf, 19; on birinci sınıf, 8; on ikinci sınıf, 32 olmak üzere toplam 178'dir.

\section{Veri Toplama Araçları}

Çalışmada veri toplama araçları olarak APS Mükemmeliyetçilik Ölçeği, Akılcı Olmayan İnançlar Ölçeği, Sosyal Onay İhtiyacı Ölçeği, Ebeveyn Sınav Kaygısı Ölçeği ve Kişisel Bilgi Formu kullanılmıştır. Ölçme araçlarının özelliklerine ilişkin bilgiler aşağıda sunulmuştur. 
APS Mükemmelliyetçilik Ölçeği. Slaney ve Johnson (1992) tarafindan geliştirilen orijinal ölçeğin ilk formu Slaney ve arkadaşları tarafından (Slaney ve Ashby, 1996; Slaney vd., 2001) revize edilmiştir. Ölçeğin revize edilen son hali "Yüksek Standartlar" (7 madde), "Düzen "(4 madde) ve"CÇelişki" (12 madde) olmak üzere üç boyut ve toplam 23 maddeden oluşmaktadır. Ölçeğin güvenirliği için hesaplanan Cronbach alfa değerleri; Yüksek Standartlar için ,85; Düzen için ,82 ve Çelişki için .91'dir. Türkçe uyarlaması Sapmaz (2006) tarafından gerçekleştirilmiştir. Uyarlama çalışmasında ölçeğin geçerliğini belirlemek için yapılan açımlayıcı faktör analizinde orijinalinde üç faktör olan yapıdan farklı olarak dört faktör ortaya çıkmıştır. Bu boyutlar, yüksek standartlar, düzen, tatminsizlik ve çelişki olarak adlandırılmıştır. Bulunan bu faktörler toplam varyansın \%50.22'sini açıklamaktadır. Benzer ölçekler geçerliğinde, çok boyutlu mükemmeliyetçilik ölçeği ile uyumlu mükemmeliyetçilik arasında .24, uyumsuz mükemmeliyetçilikle .51 korelasyon olduğu ortaya çıkmıştır. Güvenirlik hesaplamalarında ise her alt boyut için Cronbach Alfa değerleri Standartlar .72, Düzen .83, Tatminsizlik .81, Çelişki .72 olarak saptanmıştır. Olumlu mükemmeliyetçilik (Standartlar ve Düzen birleştirilmiş alt ölçekleri) için genel güvenirlik katsayıs1 .79; olumsuz mükemmeliyetçilik (Tatminsizlik ve Çelişki birleştirilmiş alt ölçekleri) için ise .82 olarak bulunmuştur.

Akılcı Olmayan Inanç Ölçeği (AOÏÖ-K). Akılcı olmayan inançları ölçmek amacıyla Türküm (2003) tarafindan üniversite öğrencileri üzerinde geliştirilen AOIÖ-K onaylanma ihtiyacı, kişilerarası ilişkiler ve ben olmak üzere üç alt boyut ve 15 maddeden oluşmaktadır. Ölçek likert tipinde olup ölçekten alınabilecek en düşük puan 15, en yüksek puan 75 'tir. Ölçekten alınan yüksek puan akılcı olmayan inanç düzeyinin yüksek olduğuna işaret etmektedir. Geçerlik çalışmaları için yapı geçerliği ve benzer ölçekler geçerliği incelenmiştir. Buna göre Açımlayıcı faktör analizi (AFA) sonucunda üç faktörün toplam varyansın \% 42.9'unu açıkladığı ortaya çıkmıştır. Benzer ölçekler geçerliğinde, Fonksiyonel Olmayan Tutumlar Ölçeği (FOTÖ) ile olumlu yönde .40 anlamlı olarak ilişkiliyken, Sınav Kaygısı ile -.03 ve Beck Depresyon Envanteri ile .16 olmak üzere anlamlı bir ilişki görülmemiştir. Güvenirlik çalışmalarında ölçeğin tümü için iç tutarlılık katsayısının .75 olduğu, test- tekrar test güvenirlik katsayısının ise .81 olduğu ortaya çıkmıştır (Türküm, 2003)

Sosyal Onay Ihtiyacı Ölçeği (SOÏÖ). Sosyal onay ihtiyacını ölçmek amacıyla Karaşar (2014) tarafından geliştirilen ölçek 5'li likert tipindedir. Ölçek 25 madde olup, sosyal onay ihtiyacına ilişkin; başkalarının duyarlılık, olumlu izlenim bırakma ve sosyal geri çekilme olmak üzere üç boyuttan oluşmaktadır. Sosyal Onay İhtiyacı Ölçeği'nden alınan puanların yüksekliği sosyal onay ihtiyacının da yükseldiğini göstermektedir. Ölçeğin geçerlik çalışmaları için Doğrulayıcı Faktör Analizi (DFA) kullanılmıştır. Ölçeğe ilişkin iki grup üzerinde yapılan DFA sonuçlarının uyum değerlerinin iyi düzeyde olduğu bulunmuştur (İlk grup için uyum iyiliği değerleri; $\mathrm{x}^{2} / \mathrm{sd}=2.11$, RMSEA= $.06, \mathrm{NNFI}=.94, \mathrm{CFI}=.95, \mathrm{RMR}=.06, \mathrm{NFI}=.90, \mathrm{IFI}=.95$ bulunurken; ikinci grup için; $\mathrm{x}^{2} / \mathrm{sd}=2.23, \mathrm{RMSEA}=.06$, $\mathrm{NNFI}=.95, \mathrm{CFI}=.96, \mathrm{RMR}=.06, \mathrm{NFI}=.92, \mathrm{IFI}=.96$ ). Ölçeğin güvenirlik değerleri ilişkin hesaplanan iç tutarlılık katsayıları alt boyutlar için sırasıyla; başkalarının yargılarına duyarlılık için .83, sosyal geri çekilme için .80, olumlu izlenim bırakma için .80 bulunmuştur. Ölçeğin genelinin iç tutarlılık katsayısı .90 'dır. Ölçeğe güvenirliğine ilişkin yapılan ön test-son test güvenirliği ise .90 olduğu ortaya çıkmıştır.

Ebeveyn Sınav Kaygısı Ölçeği (ESKÖ). Ebeveynlerin çocuklarının sınavlarına ilişkin kaygısı ölçmek amacıyla Baytemir ve İlhan (2018) tarafından geliştirilmiş̧ir. Ölçeğin geçerlik ve güvenirlik çalışmaları iki farklı çalışma grubu üzerinden gerçekleştirilmiş̧ir. Birinci çalışma grubundan elde edilen veriler üzerinden açımlayıcı ve doğrulayıcı faktör analizi (DFA) yapılmıştır. Açımlayıcı faktör analizi (AFA) sonuçlarına göre ölçeğin iki boyut ve 18 maddeden oluştuğu görülmüştür. Alanyazından yola çıkılarak bu iki faktör, kuruntu ve fizyolojik olarak adlandırılmıştır. İki boyut için açılanan toplam varyans \% 55.44'dür. AFA sonucunda elde edilen yapıyı doğrulamak için DFA yapılmış ve modelin yeterli uyum değerleri ürettiği $\left(\chi^{2} / \mathrm{df}=2.2, \mathrm{RMSEA}=.058, \mathrm{CFI}=.98\right.$, $\mathrm{NFI}=.97, \mathrm{TLI}=.98)$ görülmüştür. İkinci çalışma grubundan elde edilen veriler üzerinden ölçeğin ölçüt geçerlik çalışması yapılmıştır. Buna göre ebeveyn sınav kaygısı ile sürekli kaygı arasında .51, durumluk kaygı arasında .39 olmak üzere orta düzeyde anlamlı ilişkilerin olduğu görülmüştür. Ölçeğin güvenirliği için iki çalışma grubunda da Cronbach Alfa değerleri incelenmiş ve sırasıyla birinci ve ikinci çalışma gruplarında tüm ölçek için $.91 ; .93$, kuruntu alt boyutu için $.88 ; .88$ ve fizyolojik alt boyutu için $.91 ; .91$ olduğu görülmüştür.

\section{Verilerin Toplanması}

Veri toplama araçları ve kişisel bilgi formu, araştırmacı tarafından araştırmaya gönüllü olarak katılan öğrenci velilerine yüz yüze ve posta yoluyla uygulanmıştır. Araştırmaya katılan kişilerin yanıtları yaklaşık 30-35 dakika arası bir süre almıştır. 


\section{Verilerin Analizi}

Verilerin analizinde betimsel istatistikler, Pearson korelasyon katsayısı ve çoklu regresyon analizi yöntemlerinden olan backward yöntemi kullanılmıştır. Verilerin "doğrusallık" ve "normallik" sayıltılarına zarar verecek uç değerler olup olmadığını anlamak amacıyla Mahalanobis uzaklık değerleri hesaplanmıştır. Mahalonobis uzaklık değeri $\chi_{(6 ; 01)}^{2}=16.81$ 'den büyük 2 gözlem (multivariate outlier) değerlendirme dişında bırakılmıştır. Verilerin normal dağılımı sahip olup olmadığını belirlemek için basıklık ve çarpıklık değerleri incelenmiştir. Basıklık ve çarpıklık değerlerine bakıldığında çalışmanın verilerinin normal bir dağılama sahip olduğu görülmüştür (sosyal onay: çarpıklık, .03 ve basıklık .38; akılcı olmayan inançlar: çarpıklık, -.42 ve basıklık .20; ebeveyn sınav kaygısı: çarpıklık, .42 ve basıklık -.69, olumlu mükemmelliyetçilik: çarpıklık, -.67 ve basıklık .70; olumsuz mükkemmelliyetçilik; çarpıklık, .21 ve basıklık, -.26). Değişkenler arası ilişkiler incelendiğinde korelasyon değerleri .20 ile .51 arasında değiştiği böylece çoklu bağlantı problemi olmadığı görülmüştür.

\section{Bulgular}

Bu bölümde öncelikle değişkenler arasındaki ilişkilere ve betimsel istatistiklere yer verilmiştir. Daha sonra çoklu regresyon analizi sonuçları sunulmuştur. Tablo 1'de değişkenler arası ilişkiler ve betimsel istatistikler sunulmuştur.

Tablo 1. Değişkenler Arasındaki Pearson Korelasyon Katsayıları ve Betimsel İstatistikler

\begin{tabular}{lccccccccc}
\hline Değişkenler & $\mathbf{1}$ & $\mathbf{2}$ & $\mathbf{3}$ & $\mathbf{4}$ & $\mathbf{5}$ & $\mathbf{6}$ & $\bar{X}$ & Ss & $\boldsymbol{\alpha}$ \\
\hline Cinsiyet & & & & & & & & & \\
Sosyal Onay & -.11 & & & & & & 72.01 & 16.45 & .90 \\
Akılcı Olmayan İnançlar & -.01 & $.51^{* *}$ & & & & & 58.17 & 7.02 & .69 \\
Olumlu Mükemmeliyet & .10 & $.20^{* *}$ & $.38^{* *}$ & & & & 59.75 & 9.77 & .82 \\
Olumsuz Mükemmeliyet & -.12 & $.39^{* *}$ & $.39^{* *}$ & $.44^{* *}$ & & & 43.30 & 13.69 & .85 \\
Ebeveyn Sınav Kaygıs1 & $-.28^{* *}$ & $.31^{* *}$ & $.29^{* *}$ & $.29 * *$ & $.45^{* *}$ & & 45.16 & 15.90 & .93 \\
\hline
\end{tabular}

$N=178, * * p<.01$,

Tablo 1'de görüldüğü üzere cinsiyetin sadece ebeveyn sınav kaygısı ile anlamlı olarak ilişkili olduğu (-.28, $p<.01$ ), diğer değişkenlerle anlamlı olarak ilişkili olmadığı görülmektedir. Sosyal onay ihtiyacının en yüksek ilişkiyi akılcı olmayan inançlarla $(r=.51, p<.01)$ gösterdiği daha sonra sırasıyla olumsuz mükemmeliyetçilik, ebeveyn sınav kaygısı ve olumlu mükemmeliyetçilik ile pozitif yönde anlamlı olarak ilişkili olduğu bulunmuştur. Akılcı olmayan inançların, olumlu ve olumsuz mükemmeliyetçilikle ve ebeveyn sınav kaygısı ile pozitif yönde anlamlı olarak ilişkili olduğu görülmektedir. Hem olumlu hem de olumsuz mükemmeliyetçiliğin kendi aralarında ve ebeveyn sınav kaygısı ile anlamlı olarak ilişkili olduğu bulunmuştur.

Araştırmanın bağımsız değişkenleri olan cinsiyet, sosyal onay ihtiyacı, akılcı olmayan inançlar ile olumlu ve olumsuz mükemmeliyetçiliğin ebeveyn sınav kaygısını ne ölçüde yordayıp yordamadığını belirlemek amacıyla çoklu regresyon analizi yapılmış ve sonuçlar Tablo 2'de sunulmuştur. 
Tablo 2. Ebeveyn Sınav Kaygısının Yordanmasına İlişkin Çoklu Regresyon Analizi

\begin{tabular}{lllllll}
\hline Model & Yordayıcı Değişken & B & $\begin{array}{l}\text { Standart } \\
\text { Hata }\end{array}$ & $\boldsymbol{\beta}$ & $\boldsymbol{t}$ & $\boldsymbol{p}$ \\
\hline Model 1 & Sabit & 16.42 & 9.65 & & 1.701 & .09 \\
& Cinsiyet & -7.69 & 2.19 & -.23 & -3.52 & .01 \\
& Akılcı Olmayan İnançlar & .19 & .18 & .08 & 1.04 & .30 \\
& Sosyal Onay İhtiyacı & .10 & .08 & .10 & 1.29 & .20 \\
& Olumlu Mükemmeliyetçilik & .10 & .12 & .06 & .83 & .40 \\
& Olumsuz Mükemmeliyetçilik & .37 & .09 & .32 & 4.09 & .00 \\
\hline Model 2 & Sabit & 19.05 & 9.11 & & 2.09 & .04 \\
& Cinsiyet & -7.41 & 2.16 & -.23 & -3.43 & .01 \\
& Akilcı Olmayan İnançlar & .23 & .18 & .10 & 1.29 & .20 \\
& Sosyal Onay İhtiyacı & .09 & .08 & .10 & 1.24 & .22 \\
& Olumsuz Mükemmeliyetçilik & .40 & .08 & .34 & 4.74 & .00 \\
\hline Model 3 & Sabit & 19.646 & 9.112 & & 2.156 & .03 \\
& Cinsiyet & -7.67 & 2.15 & -.23 & -3.57 & .01 \\
& Akılc1 Olmayan İnançlar & .32 & .16 & .14 & 2.01 & .04 \\
& Olumsuz Mükemmeliyetçilik & .42 & .08 & .36 & 5.13 & .00 \\
& R=.52, R ${ }^{2}=.26$ & & & & & \\
\hline
\end{tabular}

Analizin ilk aşamasında (Model 1) bağımlı değişkenle en güçsüz ilişkiye sahip olan olumlu mükemmelliyetçiliğin modele katkısı az olduğundan analizden çıkartılmış $(\beta=.06, p>.05)$ arkasından (Model 2) bağımlı değişkenle ilişkisi bakımından diğer değişkenler arasında en güçsüz olan sosyal onay ihtiyacı $(\beta=.09, p>$ .05) modelden çıkartılmıştır. Böylece geriye doğru eleme (backward) yöntemi kullanılarak bağımsız değişkenler arasından modele en az katkı sağlayan değişkenler belirlenmiş ve modele dahil edilmemiştir. Buna göre nihai modelde (Model 3) sadece cinsiyetin, akılcı olmayan inançların ve olumsuz mükemmeliyetçiliğin modele anlamlı katkı sağladığı ortaya çıkmıştır. Buna göre modelin bir bütün olarak anlamlı olduğu $\left(\mathrm{R}=.52, R^{2}=.26, \mathrm{~F}=21,23\right.$, $p<.01)$ görülmektedir. Modelde yer alan değişkenlerden cinsiyet, akılcı olmayan inançlar ve olumsuz mükemmeliyetçilik ebeveyn sınav kaygısının toplam varyansını yüzde 26'sını açıklamaktadır.

Standardize edilmiş regresyon katsayısına $(\beta)$ göre sırasıyla modele en fazla katkıyı olumsuz mükemmeliyetçiliğin $(\beta=.36, p<.01)$, cinsiyetin $(\beta=-.23, p<.01)$ ve akılcı olmayan inançların $(\beta=.14, p<.05)$ sağladığı ortaya çıkmıştır. Bu sonuca göre ebeveyn sınav kaygısını açıklamakta en güçlü değişkenin olumsuz mükemmeliyetçilik olduğu görülürken cinsiyetin ikinci sırada en güçlü yordayıcı olduğu görülmüştür. Akılc1 olmayan inançların ise ilk iki değişkene göre ebeveyn sınav kaygısının daha güçsüz bir yordayıcısı olduğu bulunmuştur.

\section{Tartışma ve Sonuç}

$\mathrm{Bu}$ çalışmanın sonuçlarına göre olumsuz mükemmeliyetçilik, cinsiyet ve akılcı olmayan inançların hep birlikte ebeveyn sınav kaygısının yüzde 26'sını açıkladığı bulunmuştur. Bununla birlikte olumlu mükemmeliyetçilik ve sosyal onay ebeveyn sınav kaygısı ile anlamlı olarak ilişkili olsa da regresyon modelindeki katkıları anlamlı bulunmamıştır. Modele sırasıyla, mükemmeliyetçiliğin daha sonra cinsiyetin ve son olarak akılcı olmayan inançların katkı sağladığı ortaya çıkmıştır. Buna göre her ne kadar sosyal onay ihtiyacı ve olumlu mükemmeliyetçilik ebeveyn sınav kaygısı ile anlamlı olarak ilişsili olsa da modelde anlamlı bir katkı sağlamamıştır. Bu bulgular, alanyazındaki bulgularla tutarlılık göstermektedir. Bir çok çalışmada olumsuz mükemmeliyetçilik sınav kaygısının daha iyi bir yordayıcısıdır (Hanımoğlu ve İnanç, 2011; Eum ve Rice, 2011). Mükemmeliyetçilik genellikle olumsuz düşünülmüştür (Blatt, 1995; Pacht, 1984). Olumsuz mükemmeliyetçilikte birey çabaları asla yeterli bulmamaktadır. Olumlu mükemmeliyetçiler ise amaçlarına ulaşmak için yoğun bir şekilde çabalamakta ve bunun sonucunda hoşnutluk yaşamaktadırlar (Hamachek, 1978; Ashby ve Rice, 2002; Silverman, 2007) Buna göre çocuğunun çabalarını yeterli bulmayan ve olumsuza odaklanan ebeveynler çocuklarının sınavları konusunda daha fazla kaygı yaşıyor olabilirler. Olumlu mükemmeliyetçiliğe sahip bir ebeveyn de çocuğunun çabalarına ve başarılarına odaklaklanabilir ve böylece çocuğunun sınavlarına ilişkin daha az kaygı yaşayabilir. Örneğin, olumsuz mükemmeliyetçi tutuma sahip bir ebeveynin çocuğu bir sınavdan 100 
üzerinden 90 aldığında ebeveyn neden 100 almadığını sorarken, olumlu mükemmeliyetçi tutuma sahip ebeveyn 90 puanın gayet doyurucu olduğunu düşünebilir.

Araştırmada elde edilen bir diğer bulguya göre olumsuz mükemmeliyetçi ebeveynlerin kaygı yaşamaları gibi akılcı olmayan inançlara sahip ebeveynler de çocuğunun sınavlarına kötümser yaklaşmakta ve kaygılanmaktadır. Bu bulgu alanyazınla tutarlılık göstermektedir. Sınav kaygısı akılcı olmayan inançlardan etkilenmektedir (Güler ve Çakır, 2013; Wong, 2008). Sınavlar çocuğun ileride başarılı mesleklere girebilmesinin önemli koşullarından biri olarak düşünülebilmektedir. Birçok kişi tarafindan çocuğun sınavlardan aldığı iyi sonuçlar taktir edilmekte, sınav başarısı akademik yaşam için önemli bir gösterge olarak görülebilmektedir. $\mathrm{Bu}$ nedenle hem çocuğun kendisi hem de ailesi sınavlardan mutlaka iyi sonuçlar alınması gerekiyor düşüncesine kapılabilmektedirler. Böylece sınav hem çocukların hem de ebeveynlerin hayatını etkileyen önemli konulardan biri haline gelmektedir. Çocuğun sınava ilişkin işlevsel olmayan düşünceleri gibi (Güler ve Çakır, 2013; Wong, 2008) ebeveynin de işlevsel olmayan düşünceleri olabilmektedir. Ellis'in (2010) ifade ettiği üzere bireylerin bu akılcı olmayan inançları yaşayacakları duyguyu belirlemektedir. Akılcı olmayan inançlar, uygun olmayan sonuçlara neden olmakta, gerçekler sıklıkla abartılmakta ve aşırı genelleştirilmektedir (Elçin Boyacıoğlu ve Küçük, 2011). Çocuğum bu sınavdan mutlaka iyi bir not almalı, tüm sınavları başarmalı gibi keskin meli-malı cümleleri kuran bir ebeveyn kaygılanabilir. Ebeveynler bu şekilde düşünebileceği gibi aşırı genelleme ve durumu felaketleştiren akılcı olmayan bir inanca da sahip olabilir. Bu durumda ebeveyn çocuğum sınavdan iyi bir not alamazsa bu çok kötüdür gibi durumu felaketleştireceği gibi durumu daha fazla abartarak iyi bir not almazsa benim çocuğum başarısızdır ya da ben başarısızım sonucuna varabilecektir. Dolayısıyla akılcı olmayan bu düşünce yapısı beraberinde kaygıyı getirecektir.

Alanyazın incelendiğinde bu çalışmanın sonuçlarına benzer şekilde cinsiyetin sınav kaygısının anlamlı bir yordayıcısı olduğu görülmektedir (Trifoni ve Shahini, 2011; Chapell vd, 2015). Başka bir ifade ile kızlar erkeklere göre daha fazla sınav kaygısı yaşamaktadırlar. Bu çalışmada da kadın ebeveynlerin erkek ebeveynlere göre çocuğunun sınavlarına iliş̧in daha fazla kaygı yaşadıkları ortaya çıkmıştır. Bu durumun birçok sebebi olabilir. Öncelikle kaygı bozukluğu erkeklere oranla kadınlar arasında daha yaygındır (Feingold; 1994; McLean Asnaani, Litz ve Hofmann, 2011). Yine kişilik üzerinde yapılan çalışmalarda kızların nevrotiklik düzeylerinin erkeklere göre daha yüksek olduğu görülmektedir (Chapman, Duberstein, Sörensen ve Lyness, 2007;Tatlılığlu, 2014). Dolayısıyla sınav kaygısı gibi daha özel bir kaygı durumunda da kadınlar erkeklerden daha fazla kaygılanıyor olabilir. Cinsiyet açısından farklılaşmanın bir diğer nedeni sosyo-psikolojik süreçlerle açıklanabilir. Buna göre bu farklılaşmanın nedeni kadın ve erkeğe yüklenen toplumsal cinsiyet rolleri ile ilgili olabilir. Toplumsal cinsiyet rolleri, kadın ve erkeklerin özelliklerine ve sosyal davranışlarına ilişkin beklentilerin erken yaşlardan itibaren bireyler tarafından içselleştirilmesidir (Costa, Terracciano ve McCrae, 2001). Cinsiyet rollerinin öğrenilmesi sosyalleşme sürecinde hemcinsinin özelliklerini ve davranışlarını içselleştirilme yoluyla gerçekleşmektedir. Kadınsılık rolü daha çok yumuşak başlılık, anlayış, nezaket, diğerlerinin duygularının daha çok farkında olmakla ilişkilendirilirken erkeksilik daha çok saldırganlık, duyguların gizlenmesi, kolay heyecanlanmama, rekabetçilik gibi özelliklerle ilişkilendirilir (Ersöz, 2010). Buna göre Türk toplumunda yetişen bir kadının bir erkeğe göre daha merhametli olması, kaygılanmasının ve üzülmesinin daha normal karşılanması ve yoğun duygular yaşamasının daha kabul edilebilir olmasıyla ilişkili olabilir. Aynı zamanda Türk toplumunda kadının çocuğu yetiştirmede daha sorumlu olduğu (Özensel, 2004) düşüncesi annenin çocuğun sınavlarına ilişkin daha fazla sorumluluk hissetmesiyle sonuçlanabilir. Böylece anne, çocuğu sınavdan düşük not alacak ya da yeteri kadar başarılı olamayacak diye daha fazla endişelenebilir.

$\mathrm{Bu}$ araştırmanın bulgularına dayalı olarak psikolojik danışma alanındaki uzmanlar, ebeveynlerin sınav kaygıları üzerinde etkili olan olumsuz mükemmeliyetçilik ve akılcı olmayan inançlarını azaltmaya yönelik bireysel ve özellikle grupla psikolojik danışma çalışmaları yapılabilir. Yine ebeveynlere yönelik toplantılarda, ebeveynlerin çocuklarının sınavlarına ilişkin kaygılarını fark etmelerine ve bu kaygıların oluşumunda mükemmeliyetçi tutumun ve işlevsel olmayan düşüncelerin önemli rol oynadığına vurgu yapılabilir. Bundan sonraki ebeveyn sınav kaygısı üzerinde yapılacak çalışmalarda ebeveyn sınav kaygısını etkileyebilecek diğer kişilik özellikleri (denetim odağı, özsaygı, başarı gereksinimi, kendini kabul vb) incelenebilir. Çocukların devam ettikleri eğitim kademelerine göre, çocuklarının cinsiyetlerine, çocuklarının başarı durumlarına, sahip olunan çocuk sayısına göre ebeveyn sınav kaygısı araştırılabilir. Kadınların çocuklarının sınavlarına ilişkin daha fazla kaygı yaşadığı ortaya çıkmıştır. Bunun sosyo-psikolojik temelleri incelenebilir. Örneğin, kişilik özelliklerinin yanı sıra toplumun kadından beklentileri, kadının ev ve çocuk bakımındaki rolleri, anne ve babaların okula ilişkin velilik görevleri bu kapsamda düşünülebilir. Farklı kültürlerde ebeveynlerin çocuklarının sınavlarına ilişkin kaygı yaşamalarının belirlenmesi durumunda bu ve buna benzer modeller sinanabilir. 
Son olarak bu çalıșmanın bazı sınırlıkları vardır. Araştırma verileri Türkiye'nin kuzey bölgesindeki bir il merkezinde yaşayan öğrenci velilerinden toplanmıștır. Bu nedenle genelleme yapılırken bu durum dikkate alınmalıdır. Katılımcıların oranına bakıldığında kadın katılımcıların erkeklere göre çok daha fazla olduğu görülmektedir. Bu durum da başka bir sınırlılık olarak düşünülebilir. Gelecekteki çalışmalarda Türkiye evrenini temsil edecek geniş çaplı örneklem grupları üzerinde çalışma yapılabilir. Dolayısıyla hem bölgeler, yerleşim merkezleri arasında karşılaştırmalar yapılabilir hem de araştırmanın genellenebilirliği artar. 


\section{References}

Abdollahi, A., \& Abu Talib, M. (2015). Emotional intelligence moderates perfectionism and test anxiety among Iranian students. School Psychology International, 36(5), 498-512.

Adderholdt-Elliott, M. (1987). Perfectionism: What's bad about being too good? Minneapolis, MN: Free Spirit Press.

Alisinanoğlu, F., \& Ulutaş, İ. (2003). Çocukların kaygı düzeyleri ile annelerinin kaygı düzeyleri arasındaki ilişkinin incelenmesi [A study on the relationship between children's anxiety levels and their mother's anxiety levels]. Education \& Science, 28 (128), 65-71.

Alzamani, M. S., \& Zirak, A. (2011). Students learning and study strategies in isfahan university of medical sciences and their relationship with test anxiety. Iranian Journal of Medical Education, 11(1), 58-68.

Ashby, J. S. \& Rice, K. G. (2002). Perfectionism, dysfunctional attitudes, and self-esteem: A structural equations analysis. Journal of Counseling and Development, 80 (2), 197-204.

Baytemir, K., \& İlhan, T. (2018). Development of the exam anxiety scale for parents: a validity and reliability study. Electronic Journal of Research in Educational Psychology, 16 (1), 223-241.

Baytemir, K. (2018, April). Ebeveynler de sınav kaygısı yaşıyor mu? Sınav kaygısının yordayıcıları olarak mükemmeliyetçilik, akılcı olmayan inançlar ve ebeveyn sinav kaygısı [Do parents have test anxiety? Perfectionism, irrational beliefs, and parental exam anxiety as predictors of exam anxiety]. III.INES Education and Social Science Congress, Alanya, Turkey.

Beck, A. T. (1993). Cognitive therapy: past, present, and future. Journal of Consulting and Clinical Psychology, 61(2), 194-198.

Beck, A. T., \& Clark, D. A. (1997). An information processing model of anxiety: Automatic and strategic processes. Behaviour Research and Therapy, 35(1), 49-58.

Besharat, M. A. (2003). Parental perfectionism and children's test anxiety. Psychological Reports, 93(3_suppl), 1049-1055.

Blatt, S. J. (1995). The destructiveness of perfectionism: Implications for the treatment of depression. American Psychologist, 50, 1003-1020

Bridges, K. R., \& Harnish, R. J. (2010). Role of irrational beliefs in depression and anxiety: a review. Health, 2(08), 862-877.

Burns, D.D. (1980). The perfectionist script for self-defeat. Psychology Today, 41, 34-51.

Burstein, M., \& Ginsburg, G. S. (2010). The effect of parental modeling of anxious behaviors and cognitions in school-aged children: An experimental pilot study. Behaviour Research and Therapy, 48(6), 506-515.

Chapman, B. P., Duberstein, P. R., Sörensen, S., \& Lyness, J. M. (2007). Gender differences in Five Factor Model personality traits in an elderly cohort. Personality and Individual Differences, 43(6), 1594-1603.

Cassady, J. C., \& Johnson, R. E. (2002). Cognitive test anxiety and academic performance. Contemporary Educational Psychology, 27(2), 270-295.

Costa Jr, P. T., Terracciano, A., \& McCrae, R. R. (2001). Gender differences in personality traits across cultures: robust and surprising findings. Journal of Personality and Social Psychology, 81(2), 322-331.

Castro, J. R., \& Rice, K. G. (2003). Perfectionism and ethnicity: Implications for depressive symptoms and self-reported academic achievement. Cultural Diversity and Ethnic Minority Psychology, 9(1), 64-78.

Chang, E. C. (2000). Perfectionism as a predictor of positive and negative psychological outcomes: Examining a mediation model in younger and older adults. Journal of Counseling Psychology, 47(1), 18-26. 
Chapell, M. S., Blanding, Z. B., Silverstein, M. E., Takahashi, M., Newman, B., Gubi, A., \& McCann, N. (2005). Test anxiety and academic performance in undergraduate and graduate students. Journal of Educational Psychology, 97(2), 268-274.

Chin, E. C., Williams, M. W., Taylor, J. E., \& Harvey, S. T. (2017). The influence of negative affect on test anxiety and academic performance: An examination of the tripartite model of emotions. Learning and Individual Differences, 54, 1-8.

Ellis, A. (2010). Overcoming destructive beliefs, feelings, and behaviors: New directions for rational emotive behavior therapy. Prometheus Books.

Elçin Boyacıoğlu, N., \& Küçük, L. (2011). Ergenlikte mantık dışı inançlar sınav kaygısını nasıl etkiliyor? [How do irrational beliefs affect test anxiety during adolescence?]. Journal of Psychiatric Nursing, 2(1), 40-45.

Ergene, T. (2003). Effective interventions on test anxiety reduction a meta-analysis. School Psychology International, 24(3), 313-328.

Ersöz, A.G. (2010). Türk atasözleri ve deyimlerinde kadına yönelik toplumsal cinsiyet rolleri [Gender roles of women in turkish proverbs and idioms]. Gazi Türkiyat Türkoloji Araştırmalarl Dergisi, 1(6), 167-182.

Eum, K., \& Rice, K. G. (2011). Test anxiety, perfectionism, goal orientation, and academic performance. Anxiety, Stress, \& Coping, 24(2), 167-178.

Fehr, E., \& Falk, A. (2001). Psychological foundations of incentives. Institute for Empirical Research in Economics University of Zurich Working Paper Series. Working Paper No. 95, Paper presented at the Annual Conference of the European Economic Association.

Feingold, A. (1994). Gender differences in personality: A meta-analysis. Psychological Bulletin, 116(3), 429456.

Frost, R. O., Marten, P., Lahart, C., \& Rosenblate, R. (1990). The dimensions of perfectionism. Cognitive Therapy and Research, 14, 449-468

Güler, D., \& Çakır, G. (2013). Lise son sınıf öğrencilerinin sınav kaygısını yordayan değişkenlerin incelenmesi [Examining predictors of test anxiety levels among 12th grade high school students]. Turkish Psychological Counseling and Guidance Journal, 4(39), 82-94.

Hamachek, D. E. (1978). Psychodynamics of normal and neurotic perfectionism. Psychology, 15, 27-33.

Harpell, J. V., \& Andrews, J. J. (2012). Multi-informant test anxiety assessment of adolescents. Psychology, 3(07), 518-524.

Hembree, R. (1988). Correlates, causes, effects, and treatment of test anxiety. Review of Educational Research, 58(1), 47-77.

Heppner, P. P., Wampold, B. E., \& Kivlighan, D. M., Jr. (2013). Psikolojik danışmada araştırma yöntemleri (1. bs.) [Research design in counseling ( 1th ed.) ]. (D. M. Siyez, Çev.), Ankara: Mentis Publishing.

Hewitt, P. L., \& Flett, G. L. (1989). The Multidimensional Perfectionism Scale: Development and validation. Canadian Psychology, 30, 339.

Hong, E. (1998). Differential stability of individual differences in state and trait anxiety. Learning and Individual Differences, 10 (1), 51- 69.

Kağıtçıbaşı, Ç. (2010). Günümüzde insan ve insanlar: Sosyal psikolojiye giriş [The human and human being in our age: Introduction to social psychology]. İstanbul : Evrim Publishing.

Karaşar, B. (2014). Üniversite ögrrencilerinde sosyal onay ihtiyacının çeşitli değişkenle açısından incelenmesi [ Examining the need for social approval in terms of different variables among university student]. (Unpublished Doctoral Dissertation). Ankara Üniversitesi Eğitim Bilimleri Enstitüsü, Ankara. 
Karaşar, B., \& Öğülmüş, S. (2016). Üniversite öğrencilerinde sosyal onay ihtiyacinin çeşitli değişkenler açisindan incelenmesi [ Examining the need for social approval in terms of different variables among university student]. Journal of Uludag University Faculty of Education, 29(2), 469-495.

McDonald, A. S. (2001). The prevalence and effects of test anxiety in school children. Educational Psychology, 21(1), 89-101.

McLean, C. P., Asnaani, A., Litz, B. T., \& Hofmann, S. G. (2011). Gender differences in anxiety disorders: prevalence, course of illness, comorbidity and burden of illness. Journal of Psychiatric Research, 45(8), 1027-1035.

Milgram, N., \& Toubiana, Y. (1999). Academic anxiety, academic procrastination, and parental involvement in students and their parents. British Journal of Educational Psychology, 69(3), 345-361.

Montgomery, G. H., David, D., DiLorenzo, T. A., \& Schnur, J. B. (2007). Response expectancies and irrational beliefs predict exam-related distress. Journal of Rational-Emotive \& Cognitive-Behavior Therapy, 25(1), 17-34.

Mor, S., Day, H. I., Flett, G. L., \& Hewitt, P. L. (1995). Perfectionism, control, and components of performance anxiety in professional artists. Cognitive Therapy and Research, 19(2), 207-225.

Morris, L. W., \& Liebert, R. M. (1970). Relationship of cognitive and emotional components of test anxiety to physiological arousal and academic performance. Journal of Consulting and Clinical Psychology, 35(3), 332-337.

Özensel, E. (2004). Türk toplumunda çocuğun yetiştirilmesinde annenin rolü: Konya ili örneği [Mothers' role in raising children in Turkish society: A case of Konya ]. Journal of Values Education, 2(6), 77-96.

Pacht, A. R. (1984). Reflections on perfection. American Psychologist, 39, 386-390.

Peleg, O. (2009). Test anxiety, academic achievement, and self-esteem among Arab adolescents with and without learning disabilities. Learning Disability Quarterly, 32(1), 11-20.

Sapmaz, F. (2006). Üniversite ögrencilerinin uyumlu ve uyumsuz mükemmelliyetçilik özelliklerinin psikolojik belirti düzeyleri açısından incelenmesi [The investigation of adaptive and maladaptive perfectionsm and psychological symtoms at university student]. Unpublished Master Thesis, Sakarya Üniversitesi, Sosyal Bilimler Enstitüsü, Sakarya.

Shadach, E., \& Ganor-Miller, O. (2013). The role of perceived parental over-involvement in student test anxiety. European Journal of Psychology of Education, 28(2), 585-596.

Silverman, L. K. (2007). Perfectionism: The crucible of giftedness. Gifted Education International, 23(3), 233245.

Slaney, R. B., \& Johnson, D. P. (1992). The almost perfect scale. Unpublished manuscript, Pennsylvania State University, University Park.

Slaney, R. B., \& Ashby, J. (1996). Perfectionists: Study of a criterion group. Journal of Counseling and Development, 74(4), 393-398.

Slaney, R. B., Rice, G. K., Mobley, M., Trippi, J., \& Ashby, J. (2001). The revised almost perfect scale. Measurement and Evaluation in Counseling and Development, 34, 130-144.

Soygüt, G., Karaosmanoğlu, A., \& Çakir, Z. (2009). Erken dönem uyumsuz şemaların değerlendirilmesi: Young Şema Ölçeği Kısa Form-3'ün psikometrik özelliklerine ilişkin bir inceleme [Assessment of early maladaptive schemas: A psychometric study of the Turkish Young Schema Questionnaire-Short Form3]. Turk Psikiyatri Dergisi, 20(1), 75-84.

Soysa, C. K., \& Weiss, A. (2014). Mediating perceived parenting styles-test anxiety relationships: Academic procrastination and maladaptive perfectionism. Learning and Individual Differences, 34, 77-85. 
Tanaka-Matsumi, J., \& Kameoka, V. A. (1986). Reliabilities and concurrent validities of popular self-report measures of depression, anxiety, and social desirability. Journal of Consulting and Clinical Psychology, 54(3), 328-333.

Tatlılıoğlu, K. (2014). Üniversite öğrencilerinin beş faktör kişilik kuramına göre kişilik özellikleri alt boyutlarının bazı değişkenlere göre değerlendirilmesi [A research subscales of undergraduates' personality traits according to five factor personality theory in terms of some variants]. Journal of History School (JOHS), 7 (XVII), 939-971.

Trifoni, A., \& Shahini, M. (2011). How does exam anxiety affect the performance of university students. Mediterranean Journal of Social Sciences, 2(2), 93-100.

Türküm, A. S. (2003). Akılcı olmayan inanç ölçeğinin geliştirilmesi ve kısaltılması [The development of irrational belief scale and studies of minimizing the number of items]. Turkish Psychological Counseling and Guidance Journal, 19, 41-4

Yildırım, İ. (2007). Depression, test anxiety and social support among Turkish students preparing for the university entrance examination. Eurasian Journal of Educational Research (EJER), (29), 171-184.

Yıldırım, İ., Gençtanırım, D., Yalçın, İ., \& Baydan, Y. (2008). Academic achievement, perfectionism and social support as predictors of test anxiety. Hacettepe University Journal of Education, (34), 287-296.

Wilson, N. H., \& Rotter, J. C. (1986). Anxiety management training and study skills counseling for students on self-esteem and test anxiety and performance. The School Counselor, 34(1), 18-31.

Wong, S. (2008). The Relations of cognitive triad, dysfunctional attitudes, automatic thoughts, and irrational beliefs with test anxiety. Current Psychology, 27(3), 177-191.

Woodruff-Borden, J., Morrow, C., Bourland, S., \& Cambron, S. (2002). The behavior of anxious parents: Examining mechanisms of transmission of anxiety from parent to child. Journal of Clinical Child and Adolescent Psychology, 31(3), 364-374. 